\title{
Practice Learning Model by Using Moving Target Media for Offensive Attack of Fencing Martial Art Assessed at Motor Ability
}

\author{
Ilham Kamaruddin \\ Faculty of Sport Sciences-State University of Makassar
}

\begin{tabular}{l}
\hline \hline ARTICLE INFO \\
\hline Article History: \\
Received: $10-01-2020$ \\
Approved: $16-05-2020$ \\
\hline
\end{tabular}

\section{Key Words:}

massed practice; motor ability;

fencing attack; massed practice; kemampuan motor; serangan anggar

\section{Correspondence Address:}

Ilham Kamaruddin

Faculty of Sport Sciences

State University of Makassar

E-mail: ilham.kamaruddin@unm.ac.id

\begin{abstract}
Abstract: This study aims to determine the effect of the application of the massed practice learning model and motor ability using moving target media on fencing martial art attack skills. The research method used was an experimental method with a pre-test and post-test two group design research design. The sample used as many as 20 people with sampling techniques using simple random sample techniques through the motor ability test (Barrow Motor Ability Test). The sample was divided into two groups, namely the high motor ability group and the low motor ability group, each group consisting of ten samples. The data collection technique was using a modified fencing attack skills test (Fencing Test). The data analysis techniques in this study used the two independent sample t-test statistics. The results of this study showed that there were significant differences in the effect of the application of the massed practice learning model using moving target media in the low motor ability group and the high motor ability group. Based on the results of this study it can be concluded that the application of the massed practice learning model by using mobile target media is very effectively applied to students who have high motor skills in improving attack skills in fencing martial arts.
\end{abstract}

\begin{abstract}
Abstrak: Penelitian ini bertujuan untuk mengetahui pengaruh penerapan model pembelajaran massed practice dan kemampuan motorik menggunakan media target bergerak pada keterampilan serangan bela diri anggar. Metode penelitian yang digunakan adalah metode eksperimen dengan desain penelitian dua kelompok pre-test dan post-test. Sampel yang digunakan adalah sebanyak 20 orang dengan menggunakan teknik simple random sample melalui tes kemampuan motorik (Barrow Motor Ability Test). Sampel dibagi menjadi dua kelompok, yaitu kelompok kemampuan motorik tinggi dan kelompok kemampuan motorik rendah, masing-masing kelompok terdiri dari sepuluh sampel. Teknik pengumpulan data menggunakan tes keterampilan serangan anggar yang dimodifikasi (Fencing Test). Teknik analisis data dalam penelitian ini menggunakan dua statistik uji-t sampel independen. Hasil penelitian ini menunjukkan bahwa ada perbedaan yang signifikan dalam pengaruh penerapan model pembelajaran massed practice menggunakan media target bergerak pada kelompok kemampuan motorik rendah dan kelompok kemampuan motorik tinggi. Simpulan adalah bahwa penerapan model pembelajaran massed practice dengan menggunakan media target bergerak sangat efektif diterapkan pada siswa yang memiliki keterampilan motorik tinggi dalam meningkatkan keterampilan serangan bela diri anggar.
\end{abstract}

Learning is a process of change that occurs in behavior that comes from interactions between humans and the environment. Learning is considered to be successful if it generates a positive impact on student learning outcomes in the form of increased knowledge, attitudes and skills (Rahman et al., 2019). Mastery of learning material is a factor that influences learning outcomes improvement. The orientation of the learning process often focuses only on the results to be achieved, such as the increase in competencies acquired by students. What is meant by the competence is the active involvement of students during learning and the learning outcomes 
achieved. Unfortunately, various methods applied by lecturers tend to focus on theoretical explanation and do not emphasize on students' real competence (Tamren, 2017). Physical education constitutes a series of learning and lesson that focuses on physical activities and movements as its primary learning objectives (Rosdiani, 2014). In Physical Education, it allows students to develop their potency through physical activities and movements (Budi et al., 2019), and it also serves as essential capital for their life (Hanief \& Sugito, 2015).

Fencing martial art is one of the courses that is taught to students of Faculty of Sport Sciences. Students' achievement within fencing martial art course is indeed the responsibility of the lecturer. Fencing martial art is a sport that enables an individual to strategically play a fencing sword, foil, degen, and sable. The players are demanded to perform in both offensive and defensive playing. Fencing martial art involve two players in the confrontation of abilities, reflexes, skills and techniques, which aim to stab the opponent player (Elfateh, 2016). Fencing martial art is a type of fighting sport where every move is not only how to attack and defense with the right and appropriate technique, but also how to do them with the right time, by paying attention to the distance from the opponent's position. Some important factors for winning fencing martial art are: strength, mobility, good technique, control, temperament, timing, distance setting, and tactics (Ihsan, 2006).

The attack movement is formed starting by positioning the full motion in front of the front foot offset by the position of the buttocks which must be stable, altogether with the arms fully straightened as a straight threat and leading to the opponent, creating a forward power with the back leg repulsion accordingly the body moves. This movement is preceded by a motion to straighten the arms holding the sword, which reaches with the tip of the sword to aim and stab the opponent in the targeted area. At the same time, as the arm holding the sword, the foot is stretched reaching straight ahead in achieving full motion, with the heel of the forefoot landing on the ground first which will eventually fall in a position of full attack (Czajkowski, 2009; Sinclair \& Bottoms, 2015). Knowledge of opposing movements, evaluation of distance and visual concentration of signals are most useful learned by a fencer. When understanding distance, a fencer is ablt to prepare the right strategy to understand the position of the opponent's sword to prepare for an attack. Thus, it is very important in understanding the art of fencing in order to carry out attacks on opponents (Burdukiewicz et al., 2016; Hijazi, 2013).

According to the direct observation during the learning process of fencing martial art, it seemed that students paid less attention to the learning process and had no enthusiasm. Furthermore, students were less aware on the learning material delivered by the lecturer; it was shown by an attitude of student who did not manage to stay focus on the learning process and tended to only spin out time. In addition, students performed less active involvement during the learning process, particularly when they carried out any instruction from the lecturer. In the end of the learning process, most students were underperformed when performing fencing attacks. It was seen from the offensive movements performed by the students that were still far from the expected learning outcomes.

The above-mentioned issues influence students' learning outcomes on fencing martial art. After conducting a comprehensive observation to the students during the learning process, it obtained an answer related to students' attitude during fencing martial art lesson. Several factors have been identified as follows: the learning approach taken by the lecturer was monotonous and unvarying and it lead to student's boredom during the learning process and discouraged learning interest, the lecturer was also insufficiently capable of delivering the lesson content and it was worsened by the incapability of students in understanding the lesson content and information. Generally, the lecturer employed conventional learning model, a traditional lecturing, during the learning process. When the teacher employed conventional lecturing model, it did not allow maximum opportunities to present any movement to the students and it discouraged active participation of students. In addition, the lecturer did not utilize any available instructional me dia to make an attractive learning process. Thus, during the learning process, the students tended to be weary and it decreased their learning interest. According to the aforementioned problems, it requires a comprehensive study to increase students' learning outcomes and skills on fencing martial art lesson.

Learning process primarily aims at achieving the designated objectives. What have been acquired by students during the learning process are generated from the interaction among learning components simultaneously. Learning outcomes are commonly defined as student's improvement in terms of skills, abilities, attitude, and knowledge after undergoing learning process (KumpasLenk et al., 2018). A great deal of improvisation have been performed by teachers and educational experts to achieve the paramount goal of learning; starting from the implementation various learning method, the modification of learning method, to the development of learning strategies and model. In addition, the implementation of instructional media plays a prominent role in the success of learning process. The integration of technology could also be used to design attractive instructional media to improve students' interest and learning outcomes to achive the goal of learning (Nazarenko, 2014).

Instructional media within the learning process aims at accommodating and facilitating both teachers and students in achieving the desired objective (Ashfahany et al., 2017). Therefore, the utilization of instructional media in the learning process is essentially important. The implementation proper instructional media, moreover, allows students to learn efficiently and effectively and it offers them an accessible opportunity to acquire better understanding rather than only applying conventional lecturing method (Barlex \& Trebell, 2008). Furthermore, when the teacher is capable of applying suitable instructional media during the learning process, it automatically elevates the quality of learning that takes place in the classroom (Christensen, 2014). Hence, it is undeniable 
that the implementation of instructional media during the learning prominent serves a paramount effect to improve students' interest, learning motivation that eventually improves their learning outcomes; both tangible and intangible outcomes as well as in terms of affective, psychomotor and cognitive aspects. However, teacher must understand what kind of instructional media that is proper to create effective learning and teaching process that satisfy the learning objective (Sharma, 2013). Not to mention, when deciding to apply certain instructional media, teacher must understand the needs of students. If teacher fails to identify the needs of students and apply certain instructional media without careful consideration, it will not be able to improve the outcomes of students as well as the participation during the learning process (Yueh et al., 2012). Essentially, instructional media is applied to accommodate students in understanding lesson content and facilitate teacher to deliver lesson content. Accordingly, the instructional media used by teacher must satisfy the purpose of the learning itself (Mustaqim, 2016).

The lesson and learning in Physical education are an interesting topic to be studied and discussed since it comprises of movement process of students (Studer et al., 2010). The lecturer of Physical education regularly finds and designs effective learning model to achieve the objective of learning. Fencing martial art course allows students to practice movement practice as its primary learning objective. A great number of learning methods are available to be applied to maximize the opportunity of practicing. Particularly, in the context of Physical education, there are two models of learning design that allow students to practice the movement. One of the models is massed practice (Ahmadvand et al., 2016). During massed practice, students are involved in extensive and intensive movement practice without any break time session (Emery, 2017; Schmidt, 2015). In massed practice, an individual or group of students intensively practice the movement and they are not given a break time in each learning session (Magill \& Anderson, 2014; Studer et al., 2010).

In massed practice, students perform the entire movement series as insructed by the lecturer continously without having break time session until the lesson session is done or dismissed. If during the practice the lecturer gives them break time, it should not longer than the usual break time session. During the practice, the lecturer must actively motivate the students to avoid any possible boredom (Panchuk et al., 2013). Massed practice learning method is commonly considered as negative one since it leads to student's weariness and boredom. However, if it is seen from the practical perspective, this learning method is beneficial for those who intend to escalate their skills with a limited time allocation (Kamaruddin et al., 2019). Based on the aforementioned explanation, massed practice involves a continuous practice of movement series without having a rest. This method obliges students to constantly practice the movement as instructed by the lecturer after the time given is over. Repeating the movement as instructed is the key of the learning method.

Another factor that might influence the process of movement training is the student's motor skills (Tortella et al., 2016). Motor skills play an essential role during the movement training and sport skills lesson (Kalač \& Gontarev, 2014). Motor skills are an individual's capacity related to physical movement that allows them to perform any movement or on other words, it is defined as the ability of individual in moving their body parts (Burdukiewicz et al., 2016). In a learning process that involves motor skills, a student is expected to be able to master motor skill; a student needs to perform movement practice maximally based on their capacity (Widiastuti, 2015). The higher the motor skills of the individual, it allows them to be able to perform any movement easily (Hagemann et al., 2010). Motor skills play a role as a basic skill that differentiate each individual in developing a movement task (Kamaruddin, 2019). Before mastering a more complex movement practice, an individual must be able to perform simple movement practice (Barnett et al., 2009; Kawashima et al., 2012).

According to the aforementioned problems and some of the previous studies conducted, thus, this research aims at examining the implementation of massed practice learning model and motor skills on the student's ability in performing offensive movement in fencing martial art lesson by using moving target media. Furthermore, this study is expected to be able to provide solution to teacher/lecturer in improving the learning outcomes of students, particularly in improving the skills of fencing martial art among students. Moving target media constitutes as a target media that is continuously moving to train students' skills to stab right on the target to improve their offensive movements. The implementation of this media is expected to be able to improve students' interest and motivation in attending the learning process completely and eventually it improves the learning outcomes.

The purpose of this study was to identify the influence of massed practice learning model and motor skills by applying moving target media to improve the ability of offensive movement in fencing martial art lesson of Physical education department students in State University of Makassar. Furthermore, the results of this study is expected to be able to provide teacher/lecturer an insight to choose and design suitable learning model by applying proper instructional media to achieve the desired objectives of learning process, particularly in the context of fencing martial art lesson.

\section{METHOD}

This research method employed an experimental research approach with two group pretest-posttest design. This research was conducted in Faculty of Sport Sciences, State University of Makassar from September to November 2019. The population in the research was the students of Faculty of Sport Sciences State University of Makassar who took fencing martial art course. The subjects 
of this research were 20 students of Physical Education Department in the fifth semester from 2017 batch. The subjects were determined by using purposive sampling through motor skill tests called Barrow Motor Ability (BMA) which consisted of a throw at a target, sit and reach flexibility test, standing long jump, back up, push up, shuttle run with the reliability value of 0.86 . To obtain the sample for experimental group, it employed Maping Ordinal Pairing (MOP). Thus, it yielded two groups: high motor skills group and low motor skills group, where each group of experimental students consisted of ten people. The treatment was given to the students as much as 12 times; three times in a week.

The lesson material given in this study was en-Guard. It involved how to hold a fencing sword (grip), step forward, step backward, attacking techniques, attacking strategy with immobile target, attacking strategy with moving target, combination of attacking movements. The data about attack skills were collected before (through pre-test) and after treatment (through post-test) using the Kuhadja Fencing test that has been modified by the researcher because previously it only used targets that did not move and only assessed the results of the attack without regard to the process of movement of the attack (reliability value of 0.68 ). This test allowed students to perform an attack with a target in the form of a circle that moves like a pendulum clock while assessing the movement process (willing position, position when attacking and final position of attack) by three experts in the field of fencing martial art. This target was divided into five areas starting from the middle point with a radius of $5 \mathrm{~cm}$ (point 5), second circle with a radius of $10 \mathrm{~cm}$ (point 4), third circle with a radius of $15 \mathrm{~cm}$ (point 3), fourth circle with a radius of $20 \mathrm{~cm}$ (point 2) and the last circle with a radius of $25 \mathrm{~cm}$ (point 1). Before starting, students took the ideal attack distance, then they performed a series of attack test moves (1 step forward, 2 steps back, 1 step forward, then attack). The test started when the target was shaken, at the same time was run. The time used was 30 seconds per student. The value obtained was a combination of the motion process and points obtained when attacking through the T-score. In addition, the data were analyzed using the Statistical t-Test with a significant level of $\alpha=0.05$.

\section{RESULTS}

The presentation of data analysis result description of fencing martial art skills test conducted during pre-test and post-test in accordance with the groups compared is presented in the form of the table as follows.

Table 1. Description of data on the result of Attack skills in Fencing test for each group of motor skills

\begin{tabular}{|c|r|r|r|r|}
\hline Statistic & Low motor skills posttest & High motor skills posttest & Low motor skills pretest & High motor skills pretest \\
\hline $\mathrm{N}$ & 10 & 10 & 10 & 10 \\
\hline Min & 99.00 & 106.00 & 80.00 & 100.00 \\
\hline Max & 120.00 & 135.00 & 105.00 & 131.00 \\
\hline Mean & 108.8000 & 116.9000 & 92.9000 & 112.7000 \\
\hline Std. Dev & 6.27517 & 8.42549 & 7.26942 & 7.84927 \\
\hline
\end{tabular}

The Description of research data result of fencing martial art skills test for each group of motor skills in pre-test and posttest is shown in Table 1. The mean of fencing martial art skills with the high motor skill pre-test was 112,70 and the low motor skills was 92,90 . Whereas, the post-test of fencing martial art skills with the high motor skill was 116,90, and the low motor skill was 108.80. The result of data analysis can be seen on the Table 2 and 3 which describes the effect of the massed practice and motor skills on fencing martial art lesson.

Table 2. The Effect of the Massed Practice and Motor Skills on Offensive Skills in Fencing Martial Art Lesson

\begin{tabular}{|c|c|c|c|c|c|}
\hline Group & $\mathbf{N}$ & $\begin{array}{c}\text { Std. } \\
\text { Deviation }\end{array}$ & $\mathbf{t}$ & df & Sig. (2-tailed) \\
\hline Low motor skills Pre-test - Low motor skills Post-test & 10 & 2.74064 & 18.231 & 9 & .000 \\
\hline High motor skills Pre-test- High motor skills Post-test & 10 & 2.95146 & 4.714 & 9 & .001 \\
\hline
\end{tabular}

Table 3. The Effect of the Massed Practice and Motor Skills on Fencing Martial Art Lesson

\begin{tabular}{ccccc}
\hline \multirow{2}{*}{ Group } & \multirow{2}{*}{ Average } & \multirow{2}{*}{ Mean difference } & \multicolumn{2}{c}{ Average Equality Test } \\
\cline { 5 - 6 } & & \multirow{2}{*}{8,10} & t-value & Sig. \\
\hline High Motor Skill & 116,90 & & 2,498 & 0,022 \\
\hline
\end{tabular}


The results of the data analysis shown in table 2 and table 3 confirm that: There is a significant effect of the application of massed practice to the high motor skill group towards fencing martial art skill, with a probability value of $0,000(\mathrm{p}<0.05)$. There is a significant effect of the application of the massed practice to the low motor skill group towards fencing martial art skill, with a probability value of $0.001(\mathrm{p}<0.05)$. The $\mathrm{t}$-value obtained was 2.498 with a probability value of $0.022,(\mathrm{p}<0.05)$ and a mean difference of 8.10. Consequently, there is a significant difference in the effect of the application of massed practice between the low motor skill group and the high motor skill group. The average value of the final test shows that the high motor skill group experienced an increase in the outcomes of learning fencing martial art skills higher than the low motor skill group.

\section{DISCUSSION}

The main objective in this study was to determine the effect of the application of massed practice methods and motor skills to the fencing offensive skills. Based on the results of the study, there is a significant difference in the effect of applying massed practice learning models in the low motor ability group and the high motor ability group. Based on the results of data analysis, the high motor ability group showed an increase in learning outcomes of the fencing martial arts offensive skills that were higher than the low motor ability group. These results are in line with the results of research which states that with high motor skills one can learn and master a new movement (Burdukiewicz et al., 2016; Chen et al., 2017; Maas et al., 2008). This is also consistent with Lima et al's explanation, that the higher an individual's motor ability means the degree of mastery of new movements is easier (Lima et al., 2017). Correspondingly, Barnett, et al. Also explained that basic motor skills must be mastered before developing more specialized skills in sports (Barnett et al., 2009).

The learning process is said to be good if it offers many choices of learning resources (Sutrisno \& Siswanto, 2016). Instructional media is a source of learning. The use of media in learning is very important in helping to achieve learning objectives, especially supported by appropriate learning models. Based on the results of this study, the use of moving target media is very effective in improving the learning outcomes of fencing offensive skills. The results of the study are in line with studies conducted by (Gutiérrez-Dávila et al., 2013) which found that there is an increase in reaction and acceleration of time in carrying out attacks when using moving targets. This means that training using moving target media is very effective in increasing the accuracy of attack targets. Therefore, with high attack accuracy, the effectiveness in carrying out attacks is also getting better. The results of this study are also in line with the results of previous studies that apply media to improve learning outcomes, including by using audio-visual media ((Anggraini et al., 2018; Ardyanto, 2018; Arifin \& Febriyanti, 2013; Cendra et al., 2019), using interactive multimedia (Fajarwati et al., 2017; Retnosari et al., 2016), using comic media (R. Puspitorini et al., 2014), using card media (Wasilah, 2012).The implementation of learning by using the model of massed practice on students who have high motor skills in principle leads to increasing the ability of the fencing self-defense skills, because they are training with repetitive movements without a long rest period. This condition made students able to master the fencing attack skills movement better therefore the achievement of learning outcomes for fencing attack skills can be maximized. Every time an individual made a repetitive move (continously), it will indirectly be recorded into the player's long-term memory. By repeating the movement continuously (massed practice) the movement will be stored in memory for a relatively long time (Luft \& Buitrago, 2005). Before the memory is lost, the player is expected to make more movements therefore the concept of the fencing skill attack will be more accurate. Long term memory can also provide feedback to students when doing exercises hence mastery of the movements can be perfect.

The application of the massed practice learning model to fencing self-defense learning in groups of students who have high motor skills is very effective because the basic techniques of attack have a complex level of difficulty that requires more complex mastery of basic movements in mastering it. Moreover, it is beneficial if the time provided is very limited (Panchuk et al., 2013). In the massed practice learning model, this attack technique movement is carried out repeatedly with high intensity therefore the mastery of the movement will be better, moreover it is supported by high motor skills (Tangkudung et al., 2017). Thus, it is important to develop motor skills early and accordingly it is easier to master movements of high complexity (Barnett et al., 2009) since learning motor skills must start from simple movement skills to complex movement skills (Luft \& Buitrago, 2005).

When an individual having a low motor skill, they tend to be uncapable of showing a proficient movement during the training. They commonly require more time to master the movement and improve their skills. This is consistent with the results of Puspitaroni and James Tangkudung research which states that students who have low motor skills in the learning process have less potential to master complex motor skills (Puspitorini \& Tangkudung, 2016). If the motor skills possessed by students are still low, it will have an impact on the mastery of the fencing attack skills. Not only that, motor skills will also make athletes more easily perform movements in carrying out fencing martial arts attacks. This is in line with the opinion of Barnet et al, that a person must have good motor abilities to make it easier to develop more complex motion tasks (Barnett et al., 2009). Based on this, motor skills are very influential on the fencing attack skills. 
When students having high motor skills, they have the ability to quickly and easily learn new movement skills. This includes movements in fencing attack, where the learning process involves observing movements to understand the principles, forms of movement, imitating, then subsequently trying to do repetitive actions, so as to complete movement tasks effectively and efficiently, including the ability to perform a series of movements of fencing. This is in line with Tortella which states that the motor skills competency owned by a person can influence the level, amount, and intensity of motion activities (Tortella et al., 2016). Therefore motor ability is a supporting factor in learning complex motion skills (Carson Sackett \& Edwards, 2019; Edwards, 2010; Magill \& Anderson, 2014), the statement is in accordance with the results of research which states that motor skills have a significant influence on learning sports skills, not only in certain sports skills, but in many sports practices (Cigrovski et al., 2012; Kalač \& Gontarev, 2014; Nusufi, 2016).

Low motor skills of students must be supported by good learning models to more easily master the fencing attack skill movement. The massed practice learning model is a way of providing learning methods that prioritize the integrity of the motion skills learned (Kamaruddin et al., 2019; Murray, 2003). The players demonstrate the movements of the fencing skill of the fencing attack in full and are carried out repeatedly. The use of the massed practice learning model is very helpful for students who have low motor skills in mastering the fencing of a martial arts attack. This is because in massed practice learning, students are given repetition of movements with high intensity. This is very helpful for students in mastering the movement. Moreover, it is supported by the use of instructional media in the form of moving target media.

\section{CONCLUSION}

Based on data analysis above, the conclusion that can be drawn is that there are significant differences in the effects of the massed practice learning model between the low motor skills group and the high motor skills group using the moving target media. The average value of the final test shows that the increase in learning outcomes of the fence attack skills seen in the high motor skills group is higher than in the low motor skills group. Massed practice is beneficial for practitioners with limited time to train individual's skills. In fencing martial art, the level of ability of each individual depends on many variables. Motor skills are one of the factors that influence fencing martial art skills. If an individual's motor skills are high, then the easier it is to master a new movement. The level of competence of motor skills can affect the amount, intensity, and level of physical activity. Therefore, motor ability becomes a supporting factor in learning complex motion skills. In addition, the use of mobile target media is very effective in helping to achieve

learning objectives, namely to improve the learning outcomes of fencing attack skills. It is hoped that in subsequent studies, it can use other variables to improve fencing learning outcomes.

\section{ACKNOWLEDGEMENT}

The author would like to express the greatest gratitude to the Chief of Research Center of State University of Makassar for providing an assistance of this research. The author also would like to express the greatest gratitude to Faculty of Sport Sciences in providing a place for conducting this study.

\section{REFERENCES}

Ahmadvand, R., Kiani, S. M. A., \& Shojae, M. (2016). The Effect of Mass \& Distributed Practice on Performance and Learning of Discrete Simple and Complex Skills in Volleyball. Turkish Journal of Kinesiology, 2(3), 49-55.

Anggraini, A., Triansyah, A., \& Hidasari, F. P. (2018). Pengaruh Media Pembelajaran Audio Visual Keterampilan Forehand Drive Tenis Meja Penjas FKIP UNTAN 2016. Jurnal Pendidikan dan Pembelajaran Khatulistiwa, 7(7), 10.

Ardyanto, S. (2018). Peningkatan Teknik Servis Pendek pada Bulutangkis Melalui Media Audio Visual. Jurnal Ilmiah Penjas, $4(3), 12$.

Arifin, B., \& Febriyanti, I. (2013). Pengaruh Media Pembelajaran Audio Visual terhadap Hasil Belajar Senam Roll Depan (Siswa Kelas V MI Al-Azhar Modung Bangkalan). Jurnal Pendidikan Olahraga dan Kesehatan, 01(01), 222-224.

Ashfahany, F. A., Adi, S., \& Hariyanto, E. (2017). Bahan Ajar Mata Pelajaran Pendidikan Jasmani Olahraga dan Kesehatan Dalam Bentuk Multimedia Interaktif untuk Siswa Kelas VII. Jurnal Pendidikan: Teori, Penelitian, dan Pengembangan, 2(2), 261-267.

Barlex, D. M., \& Trebell, D. (2008). Design-Without-Make: Challenging the Conventional Approach to Teaching and Learning in a Design and Technology Classroom. International Journal of Technology and Design Education, 18(2), 119-138. https://doi.org/10.1007/s10798-007-9025-5

Barnett, L. M., van Beurden, E., Morgan, P. J., Brooks, L. O., \& Beard, J. R. (2009). Childhood Motor Skill Proficiency as a Predictor of Adolescent Physical Activity. Journal of Adolescent Health, 44(3), 252-259. https://doi.org/10.1016/j.jadohealth.2008.07.004 
Budi, D. R., Hidayat, R., \& Febriani, A. R. (2019). The Application of Tactical Approaches in Learning Handballs. JUARA: Jurnal Olahraga, 4(2), 131. https://doi.org/10.33222/juara.v4i2.534

Burdukiewicz, A., Pietraszewska, J., Andrzejewska, J., \& Stachoń, A. (2016). Morphological optimization of female combat sports athletes as seen by the anthropologists. Anthropological Review, 79(2), 201-210. https://doi.org/10.1515/anre-2016-0015

Carson Sackett, S., \& Edwards, E. S. (2019). Relationships among Motor Skill, Perceived Self-Competence, Fitness, and Physical Activity in Young Adults. Human Movement Science, 66, 209-219. https://doi.org/10.1016/j.humov.2019.04.015

Cendra, R., Gazali, N., \& Dermawan, M. R. (2019). The effectiveness of Audio Visual Learning Media Towards Badminton Basic Technical Skills. Jurnal SPORTIF: Jurnal Penelitian Pembelajaran, 5(1), 55. https://doi.org/10.29407/js_unpgri.v5i1.12757

Chen, W., Hammond-Bennett, A., \& Hypnar, A. (2017). Examination of Motor Skill Competency in Students: Evidence-based Physical Education Curriculum. BMC Public Health, 17(1), 222. https://doi.org/10.1186/s12889-017-4105-2

Christensen, R. (2014). Effects of Technology Integration Education on the Attitudes of Teachers and Students. Journal of Research on Technology in Education, 34(4), 411-433. https://doi.org/10.1080/15391523.2002.10782359

Cigrovski, V., Božić, I., \& Prlenda, N. (2012). Influence of Motor Abilities on Learning of Alpine SKI Technique. SportLogia, 8(2), 108-115.

Czajkowski, Z. (2009). Tactics in Fencing - Preparatory Actions. Studies in Physical Culture and Tourism, 16(4), 371-377.

Edwards, William. H. (2010). Motor Learning and Control, Theory to Practice. (1st ed.). California State University.

Elfateh, A. (2016). Effects of Ten Weeks of Instability Resistance Training (Bosu Ball) on Muscular Balance and The Learning Level of Fencing Basics. Science, Movement, and Health, 16(2), 273-279.

Emery, R. B. (2017). Spaced Versus Massed Practice in L2 German Listening Comprehension. BYU Scholars Archive, Theses and Dissertations, 6295, 142.

Fajarwati, S. K., Susilo, H., \& Indriwati, S. E. (2017). Pengaruh Project Based Learning Berbantuan Multimedia terhadap Keterampilan Memecahkan Masalah dan Hasil Belajar Psikomotor Siswa Kelas XI SMA. Jurnal Pendidikan: Teori, Penelitian, dan Pengembangan, 2(3), 315-321.

Gutiérrez-Dávila, M., Rojas, F. J., Caletti, M., Antonio, R., \& Navarro, E. (2013). Effect of Target Change During the Simple Attack in Fencing. Journal of Sports Sciences, 31(10), 1100-1107. https://doi.org/10.1080/02640414.2013.770908

Hagemann, N., Schorer, J., Cañal-Bruland, R., Lotz, S., \& Strauss, B. (2010). Visual Perception in Fencing: Do the Eye Movements of Fencers Represent their Information Pickup? Attention, Perception, \& Psychophysics, 72(8), 2204-2214. https://doi.org/10.3758/BF03196695

Hanief, Y. N., \& Sugito. (2015). Membentuk Gerak Dasar pada Siswa Sekolah Dasar melalui Permainan Tradisional. Jurnal Sportif, 1(1), 60-73.

Hijazi, M. M. K. (2013). Attention, Visual Perception and their Relationship to Sport Performance in Fencing. Journal of Human Kinetics, 39(1), 195-201. https://doi.org/10.2478/hukin-2013-0082

Kalač, R., \& Gontarev, S. (2014). Relations of Basic and Specific Motor Abilities in Boxers. Resaarch in Kinesiology, 42(2), 122127.

Kamaruddin, I. (2019). Beladiri Anggar. Makassar: Nas Media Pustaka.

Kamaruddin, I., Tangkudung, J., \& Dlis, F. (2019). Application of Massed Practice Method and Motoric Ability to Fencing Martial Skills. Proceedings of the 1st International Conference on Advanced Multidisciplinary Research (ICAMR 2018). Proceedings of the $1^{\text {st }}$ International Conference on Advanced Multidisciplinary Research (ICAMR 2018), Makassar, Indonesia. https://doi.org/10.2991/icamr-18.2019.37

Kawashima, S., Ueki, Y., Kato, T., Matsukawa, N., Mima, T., Hallett, M., Ito, K., \& Ojika, K. (2012). Changes in Striatal Dopamine Release Associated with Human Motor-Skill Acquisition. PLoS ONE, 7(2), e31728. https://doi.org/10.1371/journal.pone.0031728

Kumpas-Lenk, K., Eisenschmidt, E., \& Veispak, A. (2018). Does the design of Learning Outcomes Matter from Students' Perspective? Studies in Educational Evaluation, 59, 179-186. https://doi.org/10.1016/j.stueduc.2018.07.008

Lima, R. A., Pfeiffer, K., Larsen, L. R., Bugge, A., Moller, N. C., Anderson, L. B., \& Stodden, D. F. (2017). Physical Activity and Motor Competence Present a Positive Reciprocal Longitudinal Relationship Across Childhood and Early Adolescence. Journal of Physical Activity and Health, 14(6), 440-447. https://doi.org/10.1123/jpah.2016-0473

Luft, A. R., \& Buitrago, M. M. (2005). Stages of Motor Skill Learning. Molecular Neurobiology, 32(3), 205-216. https://doi.org/10.1385/MN:32:3:205

Maas, E., Robin, D. A., Austermann Hula, S. N., Freedman, S. E., Wulf, G., Ballard, K. J., \& Schmidt, R. A. (2008). Principles of Motor Learning in Treatment of Motor Speech Disorders. American Journal of Speech-Language Pathology, 17(3), 277298. https://doi.org/10.1044/1058-0360(2008/025)

Magill, R. A., \& Anderson, D. (2014). Motor Learning and Control: Concepts and Applications (Tenth edition). McGraw-Hill. Murray, S. R. (2003). Massed versus Distributed Practice: Which is Better?. CAHPERD Journal, 28(1), 4. 
Mustaqim, I. (2016). Pemanfaatan Augmented Reality sebagai Media Pembelajaran. Jurnal Pendidikan Teknologi dan Kejuruan, $13(2), 174-183$.

Nazarenko, A. L. (2014). Information Technologies in Education: Blended Learning (an Attempt of a Research Approach). Procedia - Social and Behavioral Sciences, 154, 53-56. https://doi.org/doi:10.1016/j.sbspro.2014.10.111

Nusufi, M. (2016). Hubungan Kemampuan Motor Ability dengan Keterampilan Bermain Sepak Bola pada Klub Himadirga UNSYIAH. Jurnal Pedagogik Olahraga, 2(1), 1-10.

Panchuk, D., Spittle, M., Johnston, N., \& Spittle, S. (2013). Effect of Practice Distribution and Experience on the Performance and Retention of a Discrete Sport Skill. Perceptual and Motor Skills, 116(3), 750-760. https://doi.org/10.2466/23.30.PMS.116.3.750-760

Puspitorini, R., Prodjosantoso, A. K., Subali, B., \& Jumadi, J. (2014). Penggunaan Media Komik Dalam Pembelajaran IPA untuk Meningkatkan Motivasi dan Hasil Belajar Kognitif dan Afektif. Jurnal Cakrawala Pendidikan, 3(3), 413-420. https://doi.org/10.21831/cp.v3i3.2385

Puspitorini, W., \& Tangkudung, J. (2016). The Efect of Visualization and Motor Abilityto the Learning Outcames Badminton Skills. Jurnal of Indonesia Physical Education and Sport, 2(1).

Rahman, A., Hastuti, U. S., \& Rohman, F. (2019). Pengaruh Penggunaan Handout Antagonisme dalam Pembelajaran Biologi terhadap Hasil Belajar Kognitif. Jurnal Pendidikan: Teori, Penelitian, dan Pengembangan, 4(8), 1056-1059.

Retnosari, N., Susilo, H., \& Suwono, H. (2016). Pengaruh Model Pembelajaran Inkuiri Terbimbing Berbantuan Multimedia Interaktif terhadap Berpikir Kritis Siswa Kelas XI SMA Negeri di Bojonegoro. Jurnal Pendidikan: Teori, Penelitian, dan Pengembangan, 1(8), 1529-1535.

Rosdiani, D. (2014). Perencanaan Pembelajaran Dalam Pendidikan Jasmani dan Kesehatan. Alfabeta.

Schmidt, R. A. (2015). Motor Learning and Control: A Behavior Emphasis. Human Kinetics Publisher.

Sharma, D. P. (2013). Role of Interactive Multimedia for Enhancing Students' Achievement and Retention. International Women Online Journal of Distance Education 2(3), 12-22.

Sinclair, J., \& Bottoms, L. (2015). Gender Differences in Patellofemoral Load during the Epee Fencing Lunge. Research in Sports Medicine, 23(1), 51-58. https://doi.org/10.1080/15438627.2014.975813

Studer, B., Koeneke, S., Blum, J., \& Jancke, L. (2010). The Effects of Practice Distribution Upon the Regional Oscillatory Activity in Visuomotor Learning. Behavioral and Brain Functions, 6(1), 8. https://doi.org/10.1186/1744-9081-6-8

Sutrisno, V. L. P., \& Siswanto, B. T. (2016). Faktor-Faktor yang Mempengaruhi Hasil Belajar Siswa pada Pembelajaran Praktik Kelistrikan Otomotif SMK di Kota Yogyakarta. Jurnal Pendidikan Vokasi, 6(1), 111-120. https://doi.org/10.21831/jpv.v6i1.8118

Tamren. (2017). Penerapan Metode Inkuiri pada Mata Pelajaran Penjaskes untuk Meningkatkan Motivasi Belajar Teknik Bermain Bola Volly Siswa Kelas XI AK 1 SMK Negeri 1 Meulaboh Tahun Ajaran 2016/2017. Jurnal Umuslim, 9(11), 30-38.

Tangkudung, J., Dlis, F., \& Saleh, M. S. (2017). The Effect of Exercise and Kinesthetic Methods to Backhand Groundstroke Skills on Field Tennis Games. Journal of Indonesia Physical Education and Sport, 3(2), 193-215.

Tortella, P., Haga, M., Loras, H., Sigmundsson, H., \& Fumagalli, G. (2016). Motor Skill Development in Italian Pre-School Children Induced by Structured Activities in a Specific Playground. PLOS ONE, 11(7), e0160244. https://doi.org/10.1371/journal.pone.0160244

Wasilah, E. B. (2012). Peningkatan Kemampuan Menyimpulkan Hasil Praktikum IPA melalui Penggunaan Media Kartu. Jurnal Pendidikan IPA Indonesia, 1(1), 82-90.

Widiastuti. (2015). Tes dan Pengukuran Olahraga. Jakarta: Bumi Timur Jaya.

Yueh, H. P., Lin, W., Huang, J. Y., \& Sheen, H. J. (2012). Effect of Student Engagement on Multimedia-Assisted Instruction. Knowledge Management \& E-Learning: An International Journal, 4(3), 346-358. 